\title{
EFFECT OF HUMIC SUBSTANCES ON NUTRIENT STATUS AND YIELD OF ONION (Allium cepa L.) IN FIELD CONDITIONS
}

\author{
Anita Osvalde*,**, Andis Karlsons*, ${ }^{* *}$, Gunta Čekstere*, **, and Solveiga Maliecka** \\ * Institute of Biology, University of Latvia, Miera iela 3, Salaspils, LV-2169, LATVIA; \\ augi@email.lubi.edu.lv \\ ** State Stende Cereals Breeding Institute, p/o Dižstende, Talsu raj., LV-3258, LATVIA; \\ stende.selekcija@apollo.Iv
}

Communicated by Henriks Zenkevičs

\begin{abstract}
Humic substances (HS) extracted from various organic materials have been shown to stimulate plant growth. However, scarce information is available on the impact of different methods of application of HS on nutrient status of vegetable species, especially in soil and climate conditions of the temperate zone. The goal of the present study was to evaluate the effect of pre-plant (bulblet soaking) and foliar application of commercially-produced peat and vermicompost-derived HS preparations on nutrient status and yield of onion (Allium cepa L.) in field experiments using two farming systems - conventional and organic. Although the effect was variable between nutrients, dependent on timing, application methods and farming systems, pre-plant and foliar HS tested was hardly effective in preventing nutrient $(S, Z n, B)$ deficiencies limiting onion yield. Moreover, $H S$ induced changes that significantly reduced nutrient status of organically grown onion and had detrimental effect on yield. Although one-year results did not suggest a benefit from HS application, further studies are necessary to evaluate the possible effectiveness of peat and vermicompost extracts on onion production in Latvia.
\end{abstract}

Key words: peat and vermicompost extracts, bulblet soaking, foliar application, nutrient uptake, Allium cepa $L$.

\section{INTRODUCTION}

Currently, the major challenges for plant scientists and agronomists are to enhance crop yields in more recourseefficient and environmentally wise cropping systems. One of the potential systems involved creation of innovative means for plant nutrition and growth promotion. The urgency to emphasize the importance of humic substances (HS) and their value as fertiliser ingredients has never been more important than at present, as the content of organic matter in agricultural soils has reached drastically low levels (Loveland and Webb, 2003). The value of HS in soil fertility relates to the many functions these complex organic compounds perform. It is well established that HS improve the physical, chemical and biological properties of soil and favourably influence plant growth (Nardi et al., 2002). Although seed treatment and foliar application of HS is increasingly used in agricultural practice, the mechanism of possible growth promoting effect, usually attributed to hormone-like impact, activation of photosynthesis and improved nutrient uptake (Chen and Aviad, 1990; Fernandez et al., 1996; Kulikova et al., 2005), remains unclear.

Commonly commercial HS are extracted from different plant-derived mineral-organic materials: peat, brown coal, lignite, leonardite, and vermicompost (Chen et al., 2004a;
Theunisen et al., 2010). While these products as nonconventional additives are currently used in commercial crop production worldwide, the obtained results are highly inconsistent. Multiple studies have been reported on the ability of HS to stimulate plant growth and yield by increased seed germination, suppression of certain diseases, and enhanced nutrient and water uptake (Nardi et al., 2002; Chen et al., 2004b; Abdel-Mawgoud et al., 2007; Hanafy Ahmed et al., 2010). Other studies have shown no benefit of the use of humic substances. Feibert et al. (2003) and Duval et al. (1998) reported no positive response from soil and foliar HS application on production of onions (Allium cepa L.) and leafy mustard (Brassica juncea L.), respectively. Likewise, Hartz and Bottoms (2010) concluded that at typical commercial application rates in representative field soils, HS is unlikely to significantly improve nutrient uptake and productivity of lettuce (Lactuca sativa L.) and tomato (Lycoperscion esculentum Mill.). The most positive crop responses have been reported for soil and foliar applied HS on cereals, especially in southern countries (Sharif et al., 2002; Shaaban et al., 2009; Khaled and Fawy, 2011; Tahir et al., 2011).

Efficiency of HS depends not only on the type of HS, nature of source material, type of application and treatment levels, 
but also on the model system, i.e. experimental conditions, growing media and plant species (Chen and Aviad, 1990; Sharif et al., 2002; Vaughan and Linehan, 2004). Consequently, further studies on different HS products, application methods and number of test plants, especially in field conditions, are necessary. Little work has been conducted in the direction of science-based application of HS in vegetable production in soil and climate conditions of the temperate zone. Especially scarce information is available about the impact of HS on nutrient status of different vegetable species grown under organic farming system.

Onion is one of the most widely cultivated vegetable crops of great economic importance. Besides making a significant nutritional contribution to human diet, onion also has medicinal and functional properties potentially beneficial to human health (Griffiths et al., 2002; Lanzotti, 2006; Galdón et al., 2009). Onion in Latvia is the fourth major commercially important vegetable crop and is cultivated on more than 1000 ha (Anonymous, 2010). Therefore, there is an urgent need to test the possibilities of HS application for optimisation of nutrient status of conventionally and organically grown onion in Latvia, with the aim to increase crop growth and yield.

The goal of the present study was to evaluate the effect of pre-plant (bulblet soaking) and foliar application of commercially-produced peat and vermicompost-derived HS preparations on nutrient status $(\mathrm{N}, \mathrm{P}, \mathrm{K}, \mathrm{Ca}, \mathrm{Mg}, \mathrm{S}, \mathrm{Fe}, \mathrm{Mn}$, $\mathrm{Zn}, \mathrm{Cu}, \mathrm{Mo}, \mathrm{B})$ and yield of onion. Field experiments were carried out in two farming systems - conventional and organic.

\section{MATERIALS AND METHODS}

Experimental conditions. Six commercial HS preparations from peat, vermicompost, and peat-vermicompost, provided by the Scientific Research and Production Firm "Intellectual resources" Ltd (Latvia), were used in this study. The range of chemical characteristics of peat and vermicompost extracts is presented in Table 1.

The field experiments were carried out at the State Stende Cereals Breeding Institute (Latvia) in a sod podzolic light loam soil during the vegetation season of 2011. The effect of HS application was examined in two agricultural farming systems: conventional and organic. Soil chemical characteristics, determined from composite soil samples of the top 20 $\mathrm{cm}$ from the both experimental fields (conventional and organic) taken in April before the experiment establishment, are given in Table 1. Soil from the conventional field was characterised by low levels of $\mathrm{Ca}$ and $\mathrm{Mg}$, and consequently low $\mathrm{pH} / \mathrm{KCl}(5.74)$, as well as low organic matter content $(1.84 \%)$. This field with basic soil chemical properties, which in general were inappropriate for vegetable production, was used in accordance with strict rules of crop rotation. Soil conditions in the organic field to a greater extent corresponded to onion production in terms of $\mathrm{pH} / \mathrm{KCl}(6.48)$, $\mathrm{Ca}, \mathrm{Mg}$ and organic matter content $(5.70 \%)$. The concentra-

\section{Table 1}

CHEMICAL CHARACTERISTICS OF SOILS AND PEAT AND VERMICOMPOST-DERIVED HUMIC SUBSTANCES (HS) EXTRACTS USED IN THE PRESENT EXPERIMENTS FOR ONION

\begin{tabular}{l|c|c|c}
\hline Parameter & \multicolumn{2}{|c|}{$\begin{array}{c}\text { Plant available soil nutrient concentra- } \\
\text { tion }\left(\mathrm{mg} \cdot \mathrm{L}^{-1}\right) \text { in } 1 \mathrm{M} \mathrm{HCl} \mathrm{extraction}\end{array}$} & $\begin{array}{c}\text { Nutrient concentra- } \\
\text { tion range in peat } \\
\text { and vermicompost } \\
\text { extracts*, mg. } \mathrm{L}^{-1}\end{array}$ \\
\cline { 2 - 3 } & $\begin{array}{c}\text { Contional } \\
\text { field }\end{array}$ & $\begin{array}{c}\text { Organic } \\
\text { field }\end{array}$ & - \\
$\mathrm{N}$ & 43 & 53 & $6.6-37.8$ \\
$\mathrm{~K}$ & 414 & 316 & $295-326$ \\
$\mathrm{Ca}$ & 170 & 135 & $59-98$ \\
$\mathrm{Mg}$ & 1280 & 3565 & $14-31$ \\
$\mathrm{~S}$ & 200 & 855 & $32-58$ \\
$\mathrm{Fe}$ & 6 & 8 & $4.8-6.6$ \\
$\mathrm{Mn}$ & 1595 & 1025 & $0.02-0.29$ \\
$\mathrm{Zn}$ & 215 & 110 & $0.13-0.81$ \\
$\mathrm{Cu}$ & 3.70 & 1.55 & $0.04-0.53$ \\
$\mathrm{Mo}$ & 5.20 & 2.35 & $<0.1$ \\
$\mathrm{~B}$ & 0.09 & 0.04 & - \\
$\mathrm{pH} / \mathrm{KCl}$ & 0.2 & 0.4 & $6.54-7.58$ \\
Organic & 5.74 & 6.48 & $0.09-0.10$ \\
matter $(\%)$ & 1.84 & 5.70 &
\end{tabular}

* Six commercial HS preparations from peat, vermicompost, and peat-vermicompost provided by Scientific Research and Production Firm "Intellectual resources" Ltd (Latvia)

tions of micronutrients were higher in the conventional field, with the exception of B. Both soils were characterised by especially low level of S. Inorganic fertilizer (N140, $\mathrm{P} 60, \mathrm{~K} 110 \mathrm{~kg} \cdot \mathrm{ha}^{-1}$ ) were applied on the conventional field before onion planting.

The growing season in 2011 was warm and wet, particularly in July and August when the average temperature was 19.2 $\mathrm{C}$ and $16.3^{\circ} \mathrm{C}$. The mean monthly precipitation in July and August was $165 \mathrm{~mm}$ and $155 \mathrm{~mm}$, respectively, which was $190 \%$ and $178 \%$ of that of the average long-term observation (data from Stende's HMS).

Experimental scheme. Three different application methods were used for evaluation of HS preparations: (1) foliar application two times; (2) pre-plant (bulblet soaking) plus foliar application two times; (3) foliar application three times - first application at early growth stage (Table 2). Foliar sprays with $0.2 \%$ HS preparations were made at application rate provided from the producer $\left(1.5 \mathrm{~L} \cdot \mathrm{ha}^{-1}\right)$. For pre-plant treatment onion bulblets were soaked for $2 \mathrm{~h}$ in $1 \% \mathrm{HS}$ solution.

In total, 19 treatments ( 6 preparations $\times 3$ application methods + control) under conventional and 19 treatments under organic farming were set up. The field experiments were arranged in a randomised block design with four replications for a single preparation. Onion bulblets 'Centurion' were planted in May $9^{\text {th }}$. The area of each plot was $20 \mathrm{~m}^{2}$ and consisted of 4 rows, $10 \mathrm{~m}$ long, $0.5 \mathrm{~m}$ apart, with $0.07 \mathrm{~m}$ spacing between bulblets in the rows. 
APPLICATION METHODS, RATES AND TIMING OF PEAT AND VERMICOMPOST-DERIVED HS PREPARATIONS

\begin{tabular}{l|l|l}
\hline \multicolumn{1}{c}{ Application method of HS preparations* } & Application rate & Application time \\
\hline Control & - & - \\
Foliar 2 times & $1.5 \mathrm{~L} / \mathrm{ha}$ & $21 \mathrm{June}, 8 \mathrm{July}$ \\
Pre-plant treatment (bulblet soaking) & $10 \mathrm{ml} / \mathrm{L}$ for $2 \mathrm{~h}$ & $9 \mathrm{May}$ \\
Plus foliar 2 times & $1.5 \mathrm{~L} / \mathrm{ha}$ & $21 \mathrm{June}, 8 \mathrm{July}$ \\
Foliar 3 times & $1.5 \mathrm{~L} / \mathrm{ha}$ & $2 \mathrm{June}$ (early application), 21 June, 8 July
\end{tabular}

HS, humic substances. * Six commercial HS preparations from peat, vermicompost, and peat-vermicompost provided by Scientific Research and Production Firm "Intellectual resources" Ltd (Latvia)

The experimental plots were harvested by hand in the middle of August. The onion yield was recorded as $\mathrm{kg} 10 \mathrm{~m}^{-2}$.

Plant sampling and nutrient analysis. To determine the nutrient status of onion, leaf material was collected twice: 1) two weeks after the first (twofold foliar application and bulblet soaking plus twofold foliar application) or the second (threefold foliar application) foliar treatment applied on 4 July 2011, and 2) two weeks after the final foliar treatment applied on 26 July 2011. Plant samples consisted of approximately 100 most recently matured leaves randomly collected from all replicates of the single preparation treatment. Six plant samples were analysed for every HS application method. Four leaf samples were collected for the control treatment.

The plant material was oven-dried at $60{ }^{\circ} \mathrm{C}$, ground, dryashed in concentrated $\mathrm{HNO}_{3}$ vapour, and re-dissolved in $\mathrm{HCl}$ solution (3 : 100). The levels of $\mathrm{Ca}, \mathrm{Mg}, \mathrm{Fe}, \mathrm{Cu}, \mathrm{Zn}$, and Mn were estimated by AAS (Perkin Elmer Analyst 700, acetylene-air flame) (Page et al., 1982), those of N, P, Mo, $\mathrm{B}$ by colorimetry, $\mathrm{S}$ by turbidimetry, and $\mathrm{K}$ by flame photometer (Jenwey PFP7, air-propane butane flame) (Ринькис и др., 1987).

Microsoft Excel 2007 was used for data statistical processing. T-test (Two Sample Assuming Unequal Variances) at $P<0.05$ was used to determine significant differences between the HS application methods.

\section{RESULTS}

Effect of pre-plant and foliar HS treatments on nutrient uptake in plants. The effect of different application methods of HS preparations on nutrient concentration in the onion leaves at the beginning of July after the first (twofold foliar and pre-plant treatment plus twofold foliar mode) and the second (threefold foliar mode) foliar treatment is presented in Tables 3 and 4. Of the macronutrients, only $\mathrm{P}$ uptake was positively affected by application of HS on conventionally grown onion (Table 3 ). Significantly higher $\mathrm{P}$ levels were observed in treatment by bulblet soaking and foliar spray in the early growth stage of onion. There was no significant impact on P uptake after the first foliar application of HS preparations in the twofold application method. Regarding the other macronutrients, no significant differ-
Table 3

EFFECT OF DIFFERENT APPLICATION METHODS OF PEAT AND VERMICOMPOST-DERIVED HS PREPARATION ON NUTRIENT CONCENTRATIONS IN ONION LEAVES GROWN UNDER A CONVENTIONAL FARMING SYSTEM (4 JULY 2011)

\begin{tabular}{l|c|ccc}
\hline Nutrient & Control & \multicolumn{3}{|c}{ Application method of HS preparations } \\
\cline { 3 - 5 } & & Foliar 2 times* & $\begin{array}{c}\text { Bulblet dipping } \\
+ \text { foliar 2 } \\
\text { times* }\end{array}$ & Foliar 3 times** \\
\hline \multicolumn{1}{c}{$\%$} & & & & \\
$\mathrm{~N}$ & $3.30 \pm 0.10 \mathrm{a}$ & $2.96 \pm 0.07 \mathrm{a}$ & $2.88 \pm 0.08 \mathrm{a}$ & $2.90 \pm 0.10 \mathrm{a}$ \\
$\mathrm{P}$ & $0.24 \pm 0.01 \mathrm{a}$ & $0.27 \pm 0.01 \mathrm{a}$ & $0.30 \pm 0.02 \mathrm{~b}$ & $0.31 \pm 0.01 \mathrm{~b}$ \\
$\mathrm{~K}$ & $2.83 \pm 0.13 \mathrm{a}$ & $2.84 \pm 0.07 \mathrm{a}$ & $2.88 \pm 0.13 \mathrm{a}$ & $2.82 \pm 0.04 \mathrm{a}$ \\
$\mathrm{Ca}$ & $2.32 \pm 0.01 \mathrm{a}$ & $2.30 \pm 0.09 \mathrm{a}$ & $2.38 \pm 0.06 \mathrm{a}$ & $2.33 \pm 0.09 \mathrm{a}$ \\
$\mathrm{Mg}$ & $0.45 \pm 0.01 \mathrm{a}$ & $0.40 \pm 0.02 \mathrm{a}$ & $0.48 \pm 0.02 \mathrm{a}$ & $0.44 \pm 0.02 \mathrm{a}$ \\
$\mathrm{S}$ & $0.12 \pm 0.02 \mathrm{a}$ & $0.12 \pm 0.01 \mathrm{a}$ & $0.10 \pm 0.01 \mathrm{a}$ & $0.11 \pm 0.01 \mathrm{a}$ \\
$\mathrm{mg} \cdot \mathrm{kg}^{-1}$ & & & & \\
$\mathrm{Fe}$ & $101.00 \pm 3.00 \mathrm{a}$ & $80.33 \pm 7.53 \mathrm{~b}$ & $110.33 \pm 4.60 \mathrm{a}$ & $113.33 \pm 6.50 \mathrm{a}$ \\
$\mathrm{Mn}$ & $135.00 \pm 9.00 \mathrm{a}$ & $158.67 \pm 12.74 \mathrm{a}$ & $160.67 \pm 8.67 \mathrm{a}$ & $156.67 \pm 5.21 \mathrm{a}$ \\
$\mathrm{Zn}$ & $8.10 \pm 0.10 \mathrm{a}$ & $8.08 \pm 0.32 \mathrm{a}$ & $7.70 \pm 0.46 \mathrm{a}$ & $7.33 \pm 0.16 \mathrm{~b}$ \\
$\mathrm{Cu}$ & $6.60 \pm 0.60 \mathrm{a}$ & $6.23 \pm 0.14 \mathrm{a}$ & $6.97 \pm 0.20 \mathrm{a}$ & $7.70 \pm 0.20 \mathrm{a}$ \\
$\mathrm{Mo}$ & $0.80 \pm 0.10 \mathrm{a}$ & $0.67 \pm 0.06 \mathrm{a}$ & $0.98 \pm 0.02 \mathrm{a}$ & $0.96 \pm 0.02 \mathrm{a}$ \\
$\mathrm{B}$ & $12.00 \pm 1.00 \mathrm{a}$ & $13.17 \pm 0.60 \mathrm{a}$ & $16.67 \pm 0.80 \mathrm{~b}$ & $15.67 \pm 0.49 \mathrm{~b}$
\end{tabular}

HS, humic substances. *First foliar treatment or ** second foliar treatment applied before 14 July 2011. Data are means from 6 preparation treatments \pm SE for HS application method. Values for the control are means from 4 replicates \pm SE. Means with a different letter in a row were significantly different (t-test, $P<0.05)$.

ences were found between any of the treatments and the control.

Regarding micronutrients, HS-dependent propotion of micronutrient uptake in onion leaves was statistically significant only for B in the treatments using bulblet dipping and early foliar spray (threefold application). Zn accumulation significantly decreased after two foliar sprays of HS in the threefold foliar application and Fe accumulation decreased in onion leaves after the first foliar spray in twofold application.

The effect of HS treatment on nutrient uptake in the onion leaves differed under the organic farming system (Table 4). Leaf concentrations of $\mathrm{N}, \mathrm{K}, \mathrm{Ca}, \mathrm{Mg}$, and $\mathrm{S}$ were significantly reduced after the first foliar spray in 21 June (twofold application method). Bulblet soaking had negative effect on $\mathrm{N}$ and $\mathrm{S}$ accumulation. In contrast, the uptake of $\mathrm{P}$ was posi- 
EFFECT OF DIFFERENT APPLICATION METHODS OF PEAT AND VERMICOMPOST-DERIVED HS PREPARATION ON NUTRIENT CONCENTRATIONS IN ONION LEAVES GROWN UNDER AN ORGANIC FARMING SYSTEM (4 JULY 2011)

\begin{tabular}{l|c|c|cc}
\hline \multirow{2}{*}{ Nutrient } & \multirow{2}{*}{ Control } & \multicolumn{3}{|c}{ Application method of HS preparations } \\
\cline { 3 - 5 } & & Foliar 2 times* & $\begin{array}{c}\text { Bulblet dipping } \\
\text { +foliar 2 times* }\end{array}$ & Foliar 3 times** \\
\hline \multicolumn{1}{c}{$\%$} & & & & \\
$\mathrm{~N}$ & $2.67 \pm 0.20 \mathrm{a}$ & $1.88 \pm 0.10 \mathrm{~b}$ & $2.18 \pm 0.18 \mathrm{~b}$ & $2.42 \pm 0.04 \mathrm{a}$ \\
$\mathrm{P}$ & $0.24 \pm 0.02 \mathrm{a}$ & $0.31 \pm 0.01 \mathrm{~b}$ & $0.30 \pm 0.02 \mathrm{~b}$ & $0.28 \pm 0.01 \mathrm{a}$ \\
$\mathrm{K}$ & $1.92 \pm 0.22 \mathrm{a}$ & $1.38 \pm 0.06 \mathrm{~b}$ & $1.66 \pm 0.20 \mathrm{a}$ & $1.66 \pm 0.23 \mathrm{a}$ \\
$\mathrm{Ca}$ & $2.76 \pm 0.10 \mathrm{a}$ & $2.32 \pm 0.15 \mathrm{~b}$ & $2.73 \pm 0.12 \mathrm{a}$ & $2.90 \pm 0.06 \mathrm{a}$ \\
$\mathrm{Mg}$ & $0.75 \pm 0.03 \mathrm{a}$ & $0.63 \pm 0.04 \mathrm{~b}$ & $0.70 \pm 0.04 \mathrm{a}$ & $0.72 \pm 0.03 \mathrm{a}$ \\
$\mathrm{S}$ & $0.17 \pm 0.005 \mathrm{a}$ & $0.14 \pm 0.003 \mathrm{~b}$ & $0.12 \pm 0.011 \mathrm{~b}$ & $0.16 \pm 0.009 \mathrm{a}$ \\
$\mathrm{mg} \cdot \mathrm{kg}^{-1}$ & & & & \\
$\mathrm{Fe}$ & $64.00 \pm 6.20 \mathrm{a}$ & $70.33 \pm 6.40 \mathrm{a}$ & $80.67 \pm 5.21 \mathrm{a}$ & $73.67 \pm 5.50 \mathrm{a}$ \\
$\mathrm{Mn}$ & $32.0 \pm 1.20 \mathrm{a}$ & $18.67 \pm 1.54 \mathrm{~b}$ & $26.67 \pm 1.61 \mathrm{~b}$ & $23.33 \pm 2.76 \mathrm{~b}$ \\
$\mathrm{Zn}$ & $9.60 \pm 0.42 \mathrm{a}$ & $5.53 \pm 0.07 \mathrm{~b}$ & $8.90 \pm 0.48 \mathrm{a}$ & $9.10 \pm 0.38 \mathrm{a}$ \\
$\mathrm{Cu}$ & $3.0 \pm 0.28 \mathrm{a}$ & $6.90 \pm 0.17 \mathrm{~b}$ & $3.10 \pm 0.24 \mathrm{a}$ & $3.47 \pm 0.18 \mathrm{a}$ \\
$\mathrm{Mo}$ & $1.08 \pm 0.20 \mathrm{a}$ & $1.47 \pm 0.35 \mathrm{a}$ & $1.55 \pm 0.13 \mathrm{~b}$ & $1.60 \pm 0.09 \mathrm{~b}$ \\
$\mathrm{~B}$ & $16.00 \pm 0.55 \mathrm{a}$ & $11.50 \pm 0.67 \mathrm{~b}$ & $15.33 \pm 0.21 \mathrm{a}$ & $16.00 \pm 0.82 \mathrm{a}$
\end{tabular}

HS, humic substances. *First foliar treatment or ** second foliar treatment were applied before 4 July 2011.

Data are means from 6 preparation treatments \pm SE for HS application method. Values for the control are means from 4 replicates \pm SE. Means with a different letter in a row were significantly different (t-test, $P<0.05$ )

tively affected by HS treatment, except in the threefold foliar application method.

Analysis of micronutrients in organically grown onion leaves showed that all HS treatments significantly decreased Mn uptake. Increased Mo was found for treatments using bulblet dipping and early foliar spray (threefold application). In addition, the first foliar treatment in the twofold application method resulted in decreased $\mathrm{B}$ and $\mathrm{Zn}$, and increased $\mathrm{Cu}$ concentration in the onion leaves.

Nutrient concentrations in leaves of conventionally grown onion after the final foliar spray are presented in Table 5. In general, there was no promoting effect on macronutrient uptake in the onion leaves. Concentrations of $\mathrm{Ca}$ and $\mathrm{Mg}$ were significantly decreased in the treatments using bulblet dipping and foliar spray in the early growth stage. Regarding micronutrients, no changes in leaf $\mathrm{Fe}, \mathrm{Mn}, \mathrm{B}$ concentration were caused by the different HS application modes. A small but statistically significant decrease in $\mathrm{Zn}$ and increase in Mo concentration was found for twofold foliar HS treatments. HS sprays in treatments with bulblet soaking and early foliar application component also stimulated Mo accumulation in the onion leaves.

The effect of different HS preparation application methods on nutrient content in the organically grown onion leaves at the end of July (after final foliar spray) is presented in Table 6. While HS sprays in treatments with bulblet soaking component had no effect on nutrient levels in onion leaves, sig-
EFFECT OF DIFFERENT APPLICATION METHODS OF PEAT AND VERMICOMPOST-DERIVED HS PREPARATION ON NUTRIENT CONCENTRATIONS IN ONION LEAVES GROWN UNDER A CONVENTIONAL FARMING SYSTEM (26 JULY 2011)

\begin{tabular}{|c|c|c|c|c|}
\hline \multirow[t]{2}{*}{ Nutrient } & \multirow[t]{2}{*}{ Control } & \multicolumn{3}{|c|}{ Application method of HS preparations } \\
\hline & & Foliar 2 times & $\begin{array}{l}\text { Bulblet dipping } \\
+ \text { foliar } 2 \text { times }\end{array}$ & Foliar 3 times \\
\hline \multicolumn{5}{|l|}{$\%$} \\
\hline $\mathrm{N}$ & $2.70 \pm 0.05 \mathrm{a}$ & $2.65 \pm 0.12 \mathrm{a}$ & $2.49 \pm 0.06 \mathrm{a}$ & $2.56 \pm 0.05 a$ \\
\hline $\mathrm{P}$ & $0.36 \pm 0.02 \mathrm{a}$ & $0.34 \pm 0.01 \mathrm{a}$ & $0.35 \pm 0.01 \mathrm{a}$ & $0.32 \pm 0.02 \mathrm{a}$ \\
\hline $\mathrm{K}$ & $4.70 \pm 0.50 \mathrm{a}$ & $4.75 \pm 0.11 \mathrm{a}$ & $4.19 \pm 0.11 \mathrm{a}$ & $4,36 \pm 0.23 a$ \\
\hline $\mathrm{Ca}$ & $3.25 \pm 0.15 a$ & $3.82 \pm 0.42 \mathrm{a}$ & $2.26 \pm 0.06 b$ & $2.37 \pm 0.12 b$ \\
\hline $\mathrm{Mg}$ & $0.68 \pm 0.01 \mathrm{a}$ & $0.68 \pm 0.09 \mathrm{a}$ & $0.34 \pm 0.01 b$ & $0.45 \pm 0.02 b$ \\
\hline $\mathrm{S}$ & $0.07 \pm 0.01 \mathrm{a}$ & $0.07 \pm 0.004 a$ & $0.06 \pm 0.01 \mathrm{a}$ & $0.06 \pm 0.003 \mathrm{a}$ \\
\hline \multicolumn{5}{|l|}{$\mathrm{mg} \cdot \mathrm{kg}^{-1}$} \\
\hline $\mathrm{Fe}$ & $170.00 \pm 30.00 \mathrm{a}$ & $213.00 \pm 24.89 \mathrm{a}$ & $161.67 \pm 11.54 \mathrm{a}$ & $188.33 \pm 14.44 \mathrm{a}$ \\
\hline $\mathrm{Mn}$ & $147.50 \pm 4.50 \mathrm{a}$ & $130.00 \pm 11.50 \mathrm{a}$ & $123.61 \pm 13.04 \mathrm{a}$ & $148.00 \pm 13.91 \mathrm{a}$ \\
\hline $\mathrm{Zn}$ & $11.10 \pm 0.30 \mathrm{a}$ & $9.97 \pm 0.32 b$ & $10.63 \pm 0.30 \mathrm{a}$ & $10.47 \pm 0.71 a$ \\
\hline $\mathrm{Cu}$ & $6.50 \pm 0.30 \mathrm{a}$ & $5.87 \pm 0.08 \mathrm{a}$ & $6.37 \pm 0.14 \mathrm{a}$ & $4.90 \pm 0.39 b$ \\
\hline Мo & $0.65 \pm 0.001 \mathrm{a}$ & $0.83 \pm 0.02 b$ & $0.87 \pm 0.06 b$ & $0.80 \pm 0.08 b$ \\
\hline B & $17.00 \pm 1.00 \mathrm{a}$ & $17.50 \pm 0.43 a$ & $16.17 \pm 0.48 a$ & $15.50 \pm 0.22 \mathrm{a}$ \\
\hline
\end{tabular}

HS, humic substances. Data are means from 6 preparation treatments \pm SE for HS application method. Values for the control are means from 4 replicates \pm SE. Means with a different letter in a row were significantly different (t-test, $P<0.05)$.

\section{Table 6}

EFFECT OF DIFFERENT APPLICATION METHODS OF PEAT AND VERMICOMPOST-DERIVED HS PREPARATION ON NUTRIENT CONCENTRATIONS IN ONION LEAVES GROWN UNDER A ORGANIC FARMING SYSTEM (26 JULY 2011)

\begin{tabular}{|c|c|c|c|c|}
\hline \multirow[t]{2}{*}{ Nutrient } & \multirow[t]{2}{*}{ Control } & \multicolumn{3}{|c|}{ Application method of HS preparations } \\
\hline & & Foliar 2 times & $\begin{array}{l}\text { Bulblet dipping } \\
+ \text { foliar } 2 \text { times }\end{array}$ & Foliar 3 times \\
\hline \multicolumn{5}{|l|}{$\%$} \\
\hline $\mathrm{N}$ & $1.73 \pm 0.20 \mathrm{a}$ & $2.03 \pm 0.05 \mathrm{a}$ & $2.00 \pm 0.05 \mathrm{a}$ & $1.98 \pm 0.08 \mathrm{a}$ \\
\hline $\mathrm{P}$ & $0.33 \pm 0.005 a$ & $0.32 \pm 0.004 a$ & $0.34 \pm 0.11 \mathrm{a}$ & $0.33 \pm 0.006 a$ \\
\hline $\mathrm{K}$ & $1.76 \pm 0.10 \mathrm{a}$ & $2.26 \pm 0.19 b$ & $1.95 \pm 0.08 \mathrm{a}$ & $1.46 \pm 0.10 \mathrm{~b}$ \\
\hline $\mathrm{Ca}$ & $2.44 \pm 0.18 \mathrm{a}$ & $2.70 \pm 0.07 a$ & $2.65 \pm 0.04 a$ & $3.22 \pm 0.22 b$ \\
\hline $\mathrm{Mg}$ & $0.69 \pm 0.04 a$ & $0.76 \pm 0.05 a$ & $0.74 \pm 0.03 \mathrm{a}$ & $1.06 \pm 0.06 \mathrm{~b}$ \\
\hline $\mathrm{S}$ & $0.06 \pm 0.01 \mathrm{a}$ & $0.07 \pm 0.005 a$ & $0.075 \pm 0.008 \mathrm{a}$ & $0.073 \pm 0.008 \mathrm{a}$ \\
\hline \multicolumn{5}{|l|}{$\mathrm{mg} \cdot \mathrm{kg}^{-1}$} \\
\hline $\mathrm{Fe}$ & $60.00 \pm 6.10 \mathrm{a}$ & $66.50 \pm 5.89 a$ & $54.67 \pm 5.77 \mathrm{a}$ & $107.67 \pm 12.16 b$ \\
\hline Mn & $16.00 \pm 0.85 a$ & $16.00 \pm 0.65 a$ & $15.33 \pm 0.67 \mathrm{a}$ & $13.50 \pm 0.92 b$ \\
\hline $\mathrm{Zn}$ & $10.20 \pm 0.86 \mathrm{a}$ & $8.87 \pm 0.40 \mathrm{a}$ & $8.90 \pm 020 \mathrm{a}$ & $7.93 \pm 0.18 b$ \\
\hline $\mathrm{Cu}$ & $5.40 \pm 0.25 a$ & $5.03 \pm 0.10 \mathrm{a}$ & $5.57 \pm 0.22 \mathrm{a}$ & $5.27 \pm 0.51 \mathrm{a}$ \\
\hline Mo & $1.90 \pm 0.18 \mathrm{a}$ & $2.69 \pm 0.06 b$ & $2.19 \pm 0.09 a$ & $2.21 \pm 0.12 \mathrm{a}$ \\
\hline B & $15.00 \pm 0.90 \mathrm{a}$ & $13.50 \pm 0.62 \mathrm{a}$ & $13.67 \pm 0.33 a$ & $12.33 \pm 0.20 b$ \\
\hline
\end{tabular}

HS, humic substances.Data are means from 6 preparation treatments $\pm \mathrm{SE}$ for HS application method. Values for the control are means from 4 replicates \pm SE. Means with a different letter in a row were significantly different (t-test, $P<0.05$ )

nificant decrease of $\mathrm{K}, \mathrm{Mn}, \mathrm{Zn}, \mathrm{B}$ and increase of $\mathrm{Ca}, \mathrm{Mg}$ and $\mathrm{Fe}$ uptake was found for treatments using early foliar application (threefold application mode). The obtained data 
showed that twofold foliar application of HS preparations significantly promoted $\mathrm{K}$ and Mo accumulation in leaves, as compared to the control.

In general, summarizing the obtained results on effect of the pre-plant and foliar HS treatments on nutrient uptake in plants, there was no effect of the twofold foliar HS treatments on macronutrient status of conventionally grown onion. All of the other HS application methods had some positive effect on nutrient uptake (increased P) at the beginning of July, while the final HS sprays resulted in decreased macronutrient accumulation (decreased $\mathrm{Ca}, \mathrm{Mg}$ ). With respect to micronutrients, the only positive effects were found for B uptake (first sampling time at the beginning of July) in the treatments using bulblet dipping and early foliar spray component, and for Mo accumulation (at the end of July) in all HS application methods. Foliar application of $\mathrm{HS}$ preparations resulted in decreased uptake of $\mathrm{Fe}, \mathrm{Zn}, \mathrm{Cu}$ in the conventional onion leaves.

Generally, a negative impact of HS treatment on the nutrient status of organically grown onion was found at the beginning of July, especially for the twofold HS application method (N, K, Ca, Mg, S, Mn, Zn, and B). While a negligible effect on nutrient concentration in onion leaves was characteristic for the threefold foliar HS treatement at the beginning of July, after the final spray this application method caused the most pronounced changes - increased accumulation of $\mathrm{Ca}, \mathrm{Mg}$, and $\mathrm{Fe}$, as well as decreased uptake of $\mathrm{K}, \mathrm{Mn}, \mathrm{Zn}$, and B. There was almost no effect of the twofold foliar and bulblet dipping HS treatments on the nutrient status of organically grown onion at the end of July.

Changes in nutrient concentrations during the study period. In general, the levels of $\mathrm{N}$ and $\mathrm{S}$ decreased, and levels of $\mathrm{P}, \mathrm{K}, \mathrm{Ca}$, and $\mathrm{Mg}$ increased, in conventionally grown onion leaves during the vegetation season (Table 3 and 5). However, changes in $\mathrm{P}, \mathrm{Ca}$ and $\mathrm{Mg}$ concentrations induced by HS application (bulblet soaking and threefold foliar treatment) resulted in constant $(\mathrm{P}, \mathrm{Ca})$ or even decreased $(\mathrm{Mg})$ levels of these nutrients in onion leaves.

Seasonal trends for micronutrients showed increase of $\mathrm{Fe}$, $\mathrm{Zn}$ and B levels in onion leaves during July. HS-dependent stimulation of B uptake in onion leaves at the beginning of July, which was characteristic for treatments using bulblet dipping and early foliar spray (threefold application), led to an unchanged B level. Threefold foliar HS application resulted in decreased concentration of $\mathrm{Cu}$ in the onion leaves at the end of July.

Similar to conventional farming, the levels of $\mathrm{N}$ and $\mathrm{S}$ decreased and $\mathrm{P}$ levels increased for organically grown onion during the vegetation season (Table 4 and 6). No significant changes were found for $\mathrm{Ca}$ and $\mathrm{Mg}$ content. Negative effect on $\mathrm{N}$ accumulation and positive effect on $\mathrm{P}$ uptake was observed after the first foliar application of HS preparations for the twofold application method, while bulblet soaking resulted in unchanged $\mathrm{N}$ and $\mathrm{P}$ concentration during the study period.
Regarding micronutrients in the organically grown onion leaves, increase of $\mathrm{Cu}$ and $\mathrm{Mo}$, as well as decrease of $\mathrm{Mn}$ was found during July. There was no pronounced effect of the different HS treatments on seasonal dynamics of micronutrient content for the organically grown onion.

Comparison of nutrient status of onion grown in different farming systems. As inorganic fertiliser (N140, P60, $\mathrm{K} 110 \mathrm{~kg} \cdot \mathrm{ha}^{-1}$ ) was applied on the conventional field before onion planting, significantly higher concentrations of $\mathrm{N}$ and $\mathrm{K}$ in onion leaves were found for conventionally grown onion. In contrast, the leaves of organically grown onion had higher $\mathrm{Mg}$ and $\mathrm{S}$ content, but only in the beginning of July. Later these differences diminished. Also, soil Mg concentration in the organic field was more than four times higher than for the conventional field.

As it can be seen from the micronutrient concentration data, significantly higher concentrations of $\mathrm{Fe}, \mathrm{Mn}$ and $\mathrm{Cu}$ were characteristic for conventionally grown onion, and contration of Mo for organically grown onion. These differences reveal plant nutrient uptake dependence on soil nutrient concentrations and soil reaction $(\mathrm{pH} / \mathrm{KCl})$.

Effect of HS application on onion yield. The obtained data showed that the pre-plant treatment and foliar application of HS had no significant effect on the yield of the conventionally grown onion (Fig. 1 A). The average yield of onion across all HS application methods and control treatment ranged from 9.56 to $9.93 \mathrm{~kg} \cdot \mathrm{m}^{-2}$. There was a different effect of HS treatment on yield of onion grown in the organic farming system (Fig. 1 B). When compared with the control, onion yield was reduced by all HS application methods, especially in the treatment with bulblet soaking and twofold foliar sprays, resulting in onion yield that was $84 \%$ and $83 \%$ of that of the control.

\section{DISCUSSION}

The aim of the present study was to evaluate the effect of pre-plant and foliar application of commercially-produced peat and vermicompost-derived HS preparation on nutrient status and yield of onion grown in two different farming systems - conventional and organic. In general, the effect was highly variable between the nutrients studied, and dependent on the timing, application methods and farming systems. The main issue is how meaningful these changes were in regard to mineral nutrition.

The analysis of leaf material from onion grown under standard conventional practices, represented by the control treatment, showed that the mean macronutrient status was optimal till high, with the exception of deficiency of $\mathrm{S}$ (Hochmuth et al., 2009). Sulphur is an essential component of important metabolic and structural compounds in plants (Marshner, 1995). Onion is known as a S-demanding crop, as $\mathrm{S}$ is a component of secondary compounds, i.e. allin, cycloallin and thiopropanol, which not only control the taste, pungency and medicinal properties of onion, but also are 

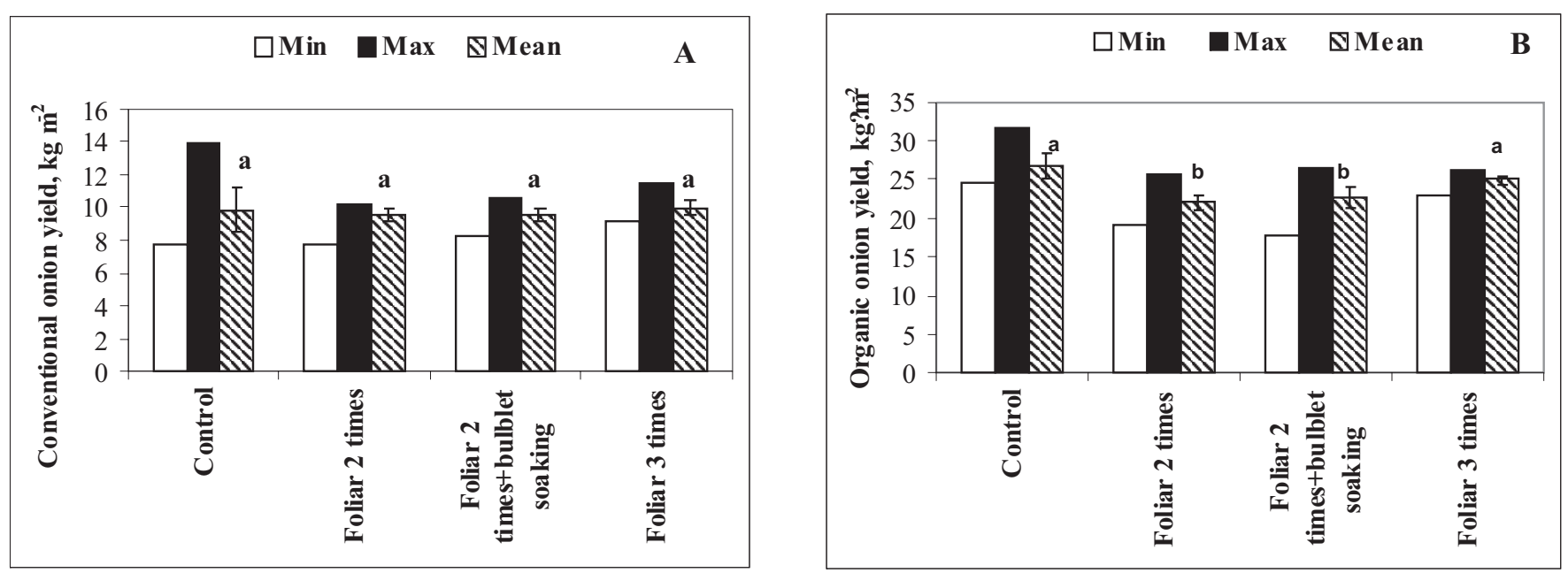

Fig. 1. Effect of different application methods of peat and vermicompost-derived humic substances preparations on onion yield $\left(\mathrm{kg} \cdot \mathrm{m}^{-2}\right.$ ) under conventional (A) and organic (B) farming systems. Data indicate the range and means from 6 preparation treatments for HS application method. Values for the control are range and means from 4 replicates. Means followed by the same letter do not differ significantly $P<0.05$.

important for resistance against pests and diseases (Schnug, 1993; Brown and Morra, 1997; Raina and Jaggi, 2008). The sulphur level in leaf tissue of onion is considered adequate within the range $0.20 \%$ to $0.60 \%$ (Jez, 2008). Our study showed that $\mathrm{S}$ concentration in onion leaves in the control treatment during the vegetation season $(0.07 \%-0.12 \%)$ did not correspond even to critically low levels of tissue standards. Unfortunately, the application of HS preparations did not result in increased S accumulation in the conventionally grown onion.

A similar situation was also found for organic grown onion - insufficient content of S in the control. It should be emphasized that the low levels of plant-available S (6-8 $\mathrm{mg} \cdot \mathrm{L}^{-1}$ ) in both soils of this experiment (Table 1) strongly indicated on a need for sulphate fertilisation. In contrast to conventional farming, the application of HS significantly reduced $\mathrm{S}$ as well as $\mathrm{N}$ and $\mathrm{K}$ content in the organically grown onion leaves at the beginning of July, resulting in declining nutrient status of organically grown onion. Such a negative effect on onion mineral nutrition was not characteristic only for the early (threefold foliar) HS application method. At the same time, all methods of HS application consistently increased $\mathrm{P}$ uptake under both conventional and organic farming systems. It is notable that values found in the control $(0.24-0.36 \% \mathrm{P})$ suggested that $\mathrm{P}$ nutrition was already in optimum range reported for onion. The concentration of $\mathrm{Ca}$ and $\mathrm{Mg}$ in all treatments for conventionally and organically grown onion was also adequate for maximum growth, based on the standards given by Rosen and Eliason (2005) and Hochmuth et al. (2009).

With respect to the micronutrients, a deficiency of $\mathrm{Zn}$ and $\mathrm{B}$ in onion leaves in the control treatment was found to be the main mineral nutrition imbalance in conventional farming. In the current study, under overall limiting $\mathrm{Zn}$ conditions in soil $\left(3.70 \mathrm{mg} \cdot \mathrm{L}^{-1}\right)$, zinc concentrations in onion leaves (8.1-11.1 $\left.\mathrm{mg} \cdot \mathrm{kg}^{-1}\right)$ were close to widely accepted critical deficiency concentrations for $\mathrm{Zn}$ for most plant species, e.g.
10-15 mg. $\mathrm{kg}^{-1}$ dry weight (Marshner, 1995; Ozturk et al., 2003). The obtained data for the first sampling time showed that HS application increased uptake of B in onion leaves, while a negative effect on $\mathrm{Zn}$ accumulation was observed. Nutrient concentrations of $\mathrm{Fe}, \mathrm{Mn}, \mathrm{Cu}$ and $\mathrm{Mo}$ in the leaves of conventionally grown onion suggested that $\mathrm{Fe}, \mathrm{Mn}, \mathrm{Cu}$ and Mo nutrition was fairly adequate (Rosen and Eliason, 2005; Hochmuth et al., 2009) and no significant differences, with the exception of slightly increased Mo, were found between any of the HS treatment methods and the control.

In general, the average values of micronutrient concentrations in organically produced onion leaves from the control plots indicated deficiency of $\mathrm{Zn}, \mathrm{Cu}, \mathrm{B}$ at the first sampling time and $\mathrm{Mn}, \mathrm{Zn}, \mathrm{Cu}, \mathrm{B}$ at the second. In contrast to some positive effects of foliar HS application in the conventional farming treatment (slightly increased B concentrations), almost only negative effects were found for organically grown onion. It is notable that all application methods resulted in decreased concentration of $\mathrm{Mn}$, and that twofold and threefold foliar treatments reduced $\mathrm{Zn}$ and B levels at different growing stages. Molybdenum was the only exception, and increased accumulation occurred in plant tissues after HS application. These concentration of Mo in onion leaves reached unnecessary high levels (up to 2.69 $\left.\mathrm{mg} \cdot \mathrm{kg}^{-1}\right)$. All these changes significantly decreased nutrient status of organically produced onion and could have detrimental impact on the plant growth and yield.

Our results are in good agreement with Fernandez et al. (1996), which suggest that when leaf nutrient values are below sufficiency ranges, foliar application of HS becomes ineffective in promoting uptake and accumulation of nutrients in leaves. Although numerous studies have been reported on the ability of HS extracted from different organic materials to stimulate nutrient $(\mathrm{N}, \mathrm{P}, \mathrm{K}, \mathrm{Fe}, \mathrm{Zn}$, etc.) uptake, this effect on vegetables has mainly been reported for soil-applied HS (Demir et al., 1999; Atiyeh et al., 2002; Selim et al., 2009). Data on a positive effect of foliar applied HS on nu- 
trient status of different crops are scarce and is usually restricted to $\mathrm{N}$ and $\mathrm{P}$ (Zaghloul et al., 2009). At application rates $\left(1.5 \mathrm{~L} \cdot \mathrm{ha}^{-1} \mathrm{HS}\right)$ used in the present experiment, HS preparations could not been considered as the direct nutrient source, and a beneficial effect of HS as a nutrient carrier or stimulator of nutrient uptake under limited nutrient conditions in soil was not indicated. It should be pointed out that the only positive response found for conventionally grown onion (increased B accumulation in leaves) was observed for the application methods using bulblet soaking and early spraying, thereby indicating that future studies need to consider the importance of the mode and timing of HS treatments.

The results of the present experiment suggest that the use of the HS additives tested under standard commercial agricultural practices and organic farming principles on a sod podzolic light loam soil did not result in any onion crop production benefit. This lack of beneficial effects of foliar application of HS agreed with the results of Feibert et al. (2003) on onion. Chen et al. (2004b) concluded that, although HS can affect plant productivity through a variety of mechanisms, foliar application of commercial humic products at typical rates provided from producers are unlikely to contain sufficient quantities of the active ingredients to result in an improvement in crop production. Chen and Aviad (1990) suggested $0.5 \mathrm{~kg} \cdot \mathrm{ha}^{-1}$ as the minimum amount of foliar-applied humic acid to elicit an increase in crop productivity. HS extracts $\left(1.5 \mathrm{~L} \cdot \mathrm{ha}^{-1}\right)$ used in our experiments supplied a total of only about $1.5 \mathrm{~g} \cdot \mathrm{ha}^{-1}$ of HS (Table 1).

In general, the two times lower productivity of the conventionally grown onion, compared to standars, could have resulted from inappropriate soil conditions, i.e. low $\mathrm{pH} / \mathrm{KCl}$ (5.74) and soil organic matter (1.84\%). Onions are classified as being very sensitive to soil acidity and do not thrive in soils below pH 6.0 because of possible trace element deficiencies (Rabinowitch and Currah, 2002). Although significantly higher concentrations of N, K (due to basic fertilisation), $\mathrm{Fe}, \mathrm{Mn}$, and $\mathrm{Cu}$ (due to higher soil concentrations and lower soil $\mathrm{pH} / \mathrm{KCl}$ ) were found in conventionally grown onion, concentrations of these nutrients were almost optimal in onion leaves of both farming systems, and thus they did not limit onion yield. In our opinion, higher S supply for organically grown onion at the beginning of July was responsible for the significantly higher onion yield production. As both soils were characterised by an especially low level of $S$ at the beginning of the experiment, the higher content of organic matter in soil of organic field could provide plant available $\mathrm{S}$ through mineralisation. The Fe:Mn ratio in plant leaves also indicated more optimal growth conditions for the organically grown onion. This study showed that the concentration of Fe was about two times higher than Mn for the organically grown onion, while for the conventionally grown onion the concentration of $\mathrm{Mn}$ was even higher than the Fe concentration. The optimal Fe:Mn in plants is about 2-2.2 (Marschner, 1995). The observed differences mainly resulted from higher mobility of $\mathrm{Mn}$ in conventional soil with lower $\mathrm{pH} / \mathrm{KCl}$.
The experiments design in two different soil conditions of course was disputable and problematic. On the other hand, such a forced situation provided the possibility to obtain additional information. In our case, foliar application of the tested HS products was generally ineffective for increasing onion yield and nutrient uptake under unfavourable growth conditions (conventional farming) or caused negative effect in more appropriate soil conditions of organic farming. Usually, the most pronounced beneficial effect of HS on plant nutrition has been reported under conditions of limited nutrient availability (Kulikova et al., 2005).

In conclusion, although the results of the present study indicate that the effect of the HS preparations on the nutrient status of onion was highly variable between nutrients, and dependent on the timing, application methods and farming systems, the foliar HS tested were hardly effective in preventing nutrient deficiencies limiting onion yield: $S, Z n$, and B. Moreover, HS induced changes that significantly lowered nutrient status of organically grown onion and had detrimental effect on yield. Although the results of one year of study did not support a benefit from the foliar application of HS preparations, further research is necessary to test the consistency of the effects reported here and evaluate possible effectiveness of peat and vermicompost extracts on onion crop production under real field and climate conditions in Latvia.

\section{ACKNOWLEDGEMENTS}

The research was supported by the ERAF, project $\mathrm{Nr}$. 2DP/2.1.1.1.0/10/APIA/VIAA/082

\section{REFERENCES}

Abdel-Mawgoud, A. M. R., El-Greadly, N. H. M., Helmy, Y. I., Singer, S. M. (2007). Responses of tomato plants to different rates of humic-based fertilizer and NPK fertilization. J. Appl. Sci. Res., 3, 169-174.

Anonymous (2010). Food and Agriculture Organisation of the United Nations. FAOSTAT.

http://faostat.fao.org/site/567/DesktopDefault.aspx?PageID=567 (last accessed 2 May 2012).

Atiyeh, R. M., Lee, S., Edwards, C. A., Arancon, N. Q., Metzger, J. D. (2002). The influence of humic acids derived from earthworm-processed organic wastes on plant growth. Bioresour. Technol., 84, 7-14.

Brown, P. D., Morra, M. J. (1997). Control of soil-born plant pests using glucosinolate containing plants. Adv. Agron., 61, 161-231.

Chen, Y., Aviad, T. (1990). Effects of humic substances on plant growth. In: MacCarthy, P., Clapp, C. E., Malcom, R. L., Bloom, P. R. (eds.). Humic Substances in Soils and Crop Science: Selected Readings (pp. 161-186). Madison: Soil Science Society of America.

Chen, Y., Clapp, C. E., Magen, H. (2004a). Mechanisms of plant growth stimulation by humic substances: The role of organic-iron complexes. Soil Sci. Plant Nutr., 50,1089-1095.

Chen, Y., De Nobili, M., Aviad, T. (2004b). Stimulatory effects of humic substances on plant growth. In: Magdoff, F., Weil, R. R. (eds.). Soil Organic Matter in Sustainable Agriculture (pp. 103-129). New York: CRC Press.

Demir, K., Gnes, A., Inal, A., Alpaslan, M. (1999). Effects of humic acids on the yield and mineral nutrition of cucumber (Cucumis sativus L.) grown with different salinity levels. Acta Hort., 492, 95-103. 
Duval, J. R., Dainello, F. J., Haby, V. A., Earhart, D. R. (1998). Evaluating leonardite as a crop growth enhancer for turnip and mustard greens. HortTechnology, 8, 564-567.

Feibert, E. B. G., Shock, C. C., Saunders, L. D. (2003). Nonconventional additives leave onion yield and quality unchanged. HortScience, 38, 381-386

Fernandez, R. E., Benlock, M., Barranco, D., Duenas, A., Ganan, J. A. G. (1996). Response of olive trees to foliar application of humic substances extracted from leonardite. Sci. Hortic., 66, 191-200.

Galdón, B. R., Rodrḳguez, C. T., Rodríguez, E. M. R., Romero, C. D. (2009). Fructans and major compounds in onion cultivars (Allium cepa). J. Food Comp. Anal., 22, 25-32.

Griffiths, G., Trueman, L., Crowther, T., Thomas, B., Smith, B. (2002). Onions - a global benefit to health. Phytother. Res. 16, 603-615.

Hanafy Ahmed, A. H., Nesiem, M. R., Hewedy, A. M., Sallam, H. El-S. (2010). Effect of some simulative compounds on growth, yield and chemical composition of snap bean plants grown under calcareous soil conditions. J. Amer. Sci., 6, 552-569.

Hartz, T. K., Bottoms, T. G. (2010). Humic substances generally ineffective in improving vegetable crop nutrient uptake or productivity. HortScience, 45, 906-910

Hochmuth, G., Maynard, D., Vavrina, C., Hanlon, E., Simonne, E. (2009). Plant Tissue Analysis and Interpretation for Vegetable Crops in Florida. University of Florida, IFAS Extension HS964, 55.

Jez, J. (eds.) (2008). Sulphur: A Missing Link Between Soils, Crops and Nutrition. Agronomy Monograph No. 50. Madison, Wisconsin: American Society of Agronomy, Crop Science Society of America, Soil Science Society of America. 329 pp.

Khaled, H., Fawy, H. A. (2011). Effect of different levels of humic acids on the nutrient content, plant growth, and soil properties under conditions of salinity. Soil Water Res., 1, 21-29.

Kulikova, N. A., Stepanova, E. V., Koroleva, O. V. (2005). Mitigating activity of humic substances: Direct influence on biota. In: Perminova, I., Hatfield, K., Hertkorn, N. (ed.). Use of Humic Substances to Remediate Polluted Environments: From Theory to Practice (pp. 285-309). Netherlands: Springer.

Lanzotti, V. (2006). The analysis of onion and garlic. J. Chromatography A, 1112, 3-22.

Loveland, P., Webb, J. (2003). Is there a critical level of organic matter in the agricultural soils of temperate regions: A review. Soil Till. Res., 70, 1-18.

Marschner, H. (1995). Mineral Nutrition in Higher Plants. London: Academic Press. 889 pp.

Maynard, D. N., Hochmuth, G. J. (1997). Knott's Handbook for Vegetable Growers, Fourth Edition. New York: John Wiley \& Sons. 600 pp.
Nardi, S., Pizzeghello, D., Muscolo, A., Vianello, A. (2002). Physiological effects of humic substances on higher plants. Soil Biol. Biochem. 34, 1527-1536.

Ozturk, L., Karanlik, S., Ozkutlu, F., Cakmak, I., Kochian, L. V. (2003). Shoot biomass and zinc/cadmium uptake for hyperaccumulator and nonaccumulator Thlaspi species in response to growth on a zinc-deficient calcareous soil. Plant Sci., 164, 1095-1101.

Page, A. L., Miller, R. H., Keeney, D. R. (eds.) (1982). Methods of Soil Analysis. Part 2. Chemical and Microbiological Properties. Madison, Wisconsin. 1159 pp.

Rabinowitch, H. D., Currah, L. (eds.) (2002). Allium Crop Science: Recent Advances. New York: CABI Publishing. 493 pp.

Raina, S. K., Jaggi, R. C. (2008). Effects of sulphur in presence and absence of farmyard manure on onion (Allium cepa) under onion-maize (Zea mays) cropping sequence. Ind. J. Agric. Sci. 78, 659-62.

Rosen, C. J., Eliason, R. (2005). Nutrient management for commercial fruit and vegetable crops in Minnesota. Minneapolis, MN: University of Minnesota Extension service, p. 26.

Schnug, E. (1993). Physiological functions and environmental relevance of sulphur containing secondary metabolites. In: De Kok, L. (Ed.). Sulphur Nutrition and Assimilation in Higher Plants (pp. 179-190). The Hague: SPB Acadamic Publishing.

Selim, E. M., Mosa, A. A., El-Ghamry, A. M. (2009). Evaluation of humic substances fertigation through, surface and subsurface drip irrigation systems on potato grown under Egyptian sandy soil conditions. Agr. Water Manag., 96, 1218-1222.

Shaaban, S. H. A., Manal, F. M., Afifi, M. H. M. (2009). Humic acid foliar application to minimize soil applied fertilization of surface irrigated wheat. World J. Agric. Sci. 5, 207-210.

Sharif, M., Khattak, R. A., Sarir, M. S. (2002). Effect of different levels of lignitic coalderived humic acid on growth of maize plants. Commun. Soil. Sci. Plant Anal., 33, 3567-3580.

Tahir, M. M., Khurshid, M., Khan, M. Z., Abbasi, M. K., Kazmi, M. H. (2011). Lignite-derived humic acid effect on growth of wheat plants in different soils. Pedosphere 21, 124-131.

Theunissen, J., Ndakidemi, P. A., Laubscher, C. P. (2010). Potential of vermicompost produced from plant waste on the growth and nutrient status in vegetable production. Int. J. Phys. Sci., 5, 1964-1973.

Vaughan, D., Linehan, D. J. (2004). The growth of wheat plants in humic acid solutions under axenic conditions. Plant Soil, 44, 445-449.

Zaghloul, S. M., El-Quesni, E. M. F., Mazhar, A. A. M. (2009). Influence of potassium humate on growth and chemical constituents of Thuja orientalis L. seedlings. Ozean J. Appl. Sci., 2, 73-78.

Ринькис Г. Я., Рамане Х. К., Куницкая Т. А. (1987). Методы анализа почв и растений [Methods of Soil and Plant Analysis]. Рига: Зинатне. 174 c. (in Russian)

Received 25 October 2012

\section{HUMUSVIELAS SATUROŠU PREPARĀTU PIELIETOŠANAS IETEKME UZ SITPOLU (Allium cepa L.) MINERĀLU BAROŠANOS UN RAŽU LAUKA APSTĀKL,OS.}

Daudzi pētījumi visā pasaulē liecina par dažādas izcelsmes humusvielu (HV) preparātu stimulējošu ietekmi uz augu augšanu. Tomēr salīdzinoši maz un pretrunīgi dati iegūti par sēklas materiāla apstrādes un HV foliāras pielietošanas ietekmi uz dārzeņu minerālo barošanos dažādos augsnes un klimatiskajos apstākḷos. Pētījuma mērkis — izvērtēt kūdras un vermikomposta ekstraktu dažādu pielietošanas metožu (vairsīpoliṇu mērcēšana un foliāri) ietekmi uz sīpolu minerālo barošanos konvencionālajā un bioloğiskajā saimniekošanas sistēmā. Lauka izmēǵinājumi iekārtoti Valsts Stendes graudaugu selekcijas institūtā 2011. gada veǵetācijas sezonā. Lai arī konstatēta atšķirīga ietekme uz barības elementu uzņemšanu atkarībā no HV pielietošanas metodes, laika un saimniekošanas sistēmas, pētāmie preparāti nebija efektīivi sīpolu ražības ierobežojošo barības elementu $(\mathrm{S}, \mathrm{Zn}, \mathrm{B})$ deficīta novēršanai. Jāatzīmē HV preparātu pielietošanas visumā bremzējošā ietekme uz barības elementu uzņemšanu bioloǵiskā lauka sīpoliem, kas varēja negatīvi ietekmēt ražas veidošanos. Lai arī viena gada izmēǵinājumi neapstiprināja kūdras un vermikomposta ekstraktu pielietošanas pozitīvu ietekmi uz sīpolu ražību un barības elementu akumulāciju, pētījumi turpināmi, lai iegūtu pārliecinošus rezultātus. 